\title{
Low Grade
}

National Cancer Institute

\section{Source}

National Cancer Institute. Low Grade. NCI Thesaurus. Code C14161.

Used to describe tumor samples that exhibit well to moderately well differentiated cells.

They are generally expected to be slow growing and less aggressive. 